\title{
Internalisasi Nilai-Nilai Nasionalisme dalam Pembelajaran PPKN di Madrasah Ibtidaiyah Maarif Condro Jember
}

\author{
Dwi Fitria Riska \\ MI Maarif Condro Jember \\ riskadwifitria2@gmail.com
}

\begin{abstract}
Abstrak
Nilai-nilai Nasionalisme yang diterapkan peserta didik dalam kegiatan pembelajaran di Madrasah Ibtidaiyah Maarif Condro Jember seringkali terkesan dikesampingkan. Hal ini dilihat dari kurangnya kesadaran peserta didik terhadap nilai moral dan Nasionalisme, seperti tidak mentaati peraturan sekolah, tidak menghargai teman, membolos, tidak mampu menghafal sila pancasila serta lagu Indonesia raya. Masih dijumpai peserta didik berperilaku dan bersikap belum baik atau masih rendah terhadap nilai-nilai nasionalisme. Penelitian ini bertujuan untuk mendeskripsikan: 1) Strategi internalisasi nilai nasionalisme pada pembelajaran PPKN di Madrasah Ibtidaiyah Maarif Condro Jember. 2) Penerapan nilai karakter nasionalisme yang dilakukan pada pembelajaran PPKN di Madrasah Ibtidaiyah Maarif Condro Jember. Hasil penelitian menunjukkan bahwa: 1) Strategi internalisasi nilai-nilai nasionalisme dalam pembelajaran PPKN ini adalah mamasukkan nilai-nilai nasionalisme dalam pembelajaran PPKN melalui pendekatan-pendekatan yang mampu diterima oleh peserta didik agar peserta didik bisa menjadi warga negara yang baik dan bisa memberikan kontribusi dalam memajukan bangsanya dimasa depan. 2) Penerapan nilai karakter nasionalisme dalam pembelajaran PPKN melalui mediator keteladanan guru dan kegiatan praktik langsung melalui pengalaman belajar seperti model pembelajaran, metode pembelajaran, bahan ajar, dan evaluasi pembelajaran. Perilaku berkarakter nasionalis yang diaktualisasikan dalam kehidupan sehari-hari di sekolah oleh siswa yaitu disiplin, cinta tanah air, semangat kebangsaan, cinta damai, peduli lingkungan, menghargai prestasi, dan toleransi.
\end{abstract}

Kata Kunci: Internalisasi; Nilai Nasionalisme; Pembelajaran PPKN 


\section{PENDAHULUAN}

Pada dasarnya, nilai Nasionalisme yang diterapkan di sekolah atau madrasah yaitu membangun karakter yang berarti bersifat memperbaiki, membina, mendirikan, mengadakan sesuatu. Sedangkan "Karakter" secara definitif adalah tabiat, watak, sifat-sifat kejiwaan, akhlak atau budi pekerti yang membedakan seseorang dari yang lain. Dalam konteks ini adalah suatu proses atau usaha yang dilakukan untuk membina, memperbaiki dan atau membentuk tabiat, watak, sifat kejiwaan, akhlak mulia, iman manusia sehingga menunjukkan perangai dan tingkah laku yang baik berlandaskan nilai-nilai Pancasila.

Nilai-nilai Nasionalisme yang diterapkan pada peserta didik dalam kegiatan pembelajaran di Madrasah Ibtidaiyah Maarif Condro Jember sedikit terkesan dikesampingkan. Kurangnya kesadaran peserta didik akan nilai moral dan Nasionalisme, seperti tidak mentaati peraturan sekolah, tidak menghargai teman, membolos, tidak mampu menghafal sila pancasila serta lagu Indonesia Raya. Masih banyak peserta didik berperilaku dan bersikap belum baik atau masih rendah terhadap nilai-nilai nasionalisme.

Berdasarkan hasil observasi di Madrasah Ibtidaiyah Maarif Condro Jember, bahwa ada beberapa siswa tidak hafal sila pancasila serta lagu Indonesia Raya, tidak mentaati peraturan sekolah, tidak menghargai teman, juga sering membolos. ${ }^{1}$ Hasil observasi tersebut juga diperkuat melalui hasil wawancara dengan salah satu guru di Madrasah Ibtida'iyah Maarif Condro Jember yang mengatakan bahwa:

Kegiatan yang ada di Sekolah yang berhubungan dengan nilai-nilai Nasionalisme bisa dikatakan ada, namun belum terlaksana secara maksimal. Contonya saja, kegiatan perlombaan baris berbaris (PBB) yang diikuti oleh peserta didik saat memperingati hari ulang tahun Republik Indonesia (HUT RI) dan kegiatan memperingati hari pahlawan seperti hari Kartini di isi dengan kegiatan peserta didik menggunakan pakaian kebaya dan pakaian batik. Namun, kegiatan ini

\footnotetext{
${ }^{1}$ Observasi, Jember, 06 Februari 2020.
} 
belum berjalan dengan maksimal, karena tidak semua peserta didik mengikuti kegiatan tersebut. ${ }^{2}$

Hasil wawancara dengan salah satu peserta didik di Madrasah Ibtida'iyah Marif Condro Jember, terkait alasan kenapa tidak mengikuti kegiatan yang mengandung nilai Nasionalisme tersebut, mengatakan bahwa:

Saya memang tidak suka dengan kegiatan perlombaan baris berbaris (PBB) dan tidak mengikuti kegiatan hari Kartini, karena tidak memiliki kebaya dan batik yang cocok untuk digunakan, Ibu guru juga tidak mewajibkan mengikutinya. ${ }^{3}$

Berkaitan dengan hal tersebut, penanaman nilai-nilai nasionalisme dalam proses pembelajaran pendidikan Pancasila dan kewarganegaraan saja dirasa tidak cukup untuk memberikan pemahaman kepada peserta didik tentang penerapan nilai-nilai Nasionalisme dalam proses pembelajaran di sekolah. Proses pembelajaran dan penanaman nilai- nilai nasionalisme tidak cukup hanya melalui proses formal di dalam kelas, namun juga harus ada kegiatan-kegiatan sekolah yang mampu memberikan pengetahuan tentang nilai-nilai nasionalisme yang ada disekolah. Internalisasi nilai-nilai nasionalisme yang diberikan pada peserta didik secara langsung merupakan salah satu faktor penting yang dirasa oleh penulis mampu menumbuhkan pengamalan nilai-nilai nasionalisme di lembaga pendidikan sekolah dan madrasah.

Adapun yang dimaksud dengan nasionalisme secara konsepsional adalah suatu paham yang menganggap kesetiaan tertinggi atas setiap pribadi harus disertakan pada negara kebangsaan (Nation State) atau sebagai sikap mental atau tingkah laku individu ataupun masyarakat yang menunjukan adanya loyalitas dan pengabdian yang tinggi terhadap bangsa dan negaranya. ${ }^{4}$ Nasionalisme sangat diperlukan dalam kelangsungan suatu negara, dengan harapan dapat memunculkan rasa persatuan dan kesatuan

\footnotetext{
${ }^{2}$ Rismala, Wawancara, Jember, 06 Februari 2020.

${ }^{3}$ Haqi, Wawancara, Jember, 06 Februari 2020.

${ }^{4}$ Muhammad Mustari, Nilai Karakter Refleksi untuk Pendidikan, (Jakarta: PT Raja Grafindo, 2014), 216.
} 
serta sikap patriotisme kepada negara. ${ }^{5}$ Nasionalisme di era globalisasi saat ini, mulai terasa berkurang, terutama bagi kalangan pelajar. Masuknya kebudayaan asing dari luar yang tidak sesuai dengan kebudayaan Indonesia memunculkan beberapa masalah yang nantinya juga berpengaruh terhadap nasionalisme generasi muda.

Nasionalisme sangat penting bagi terhadap kehidupan berbangsa dan bernegara terutama bagi generasi-generasi penerus bangsa, karena nilai tersebut merupakan wujud kecintaan dan kehormatan terhadap bangsa sendiri. Dengan hal itu, pemuda dapat melakukan sesuatu yang terbaik bagi bangsanya, menjaga keutuhan persatuan dan kesatuan bangsa serta meningkatkan martabat bangsa agar tidak mengancam dan menghancurkan keutuhan bangsa Indonesia. Dalam upaya penanaman nilai-nilai nasionalisme pada generasi muda, terutama pelajar, dapat dilakukan melalui jalur pendidikan, karena rasa nasionalisme tidak dapat terbentuk begitu saja. Melalui lembaga pendidikan, nasionalisme pada pemuda dapat terbentuk. Pendidikan nasionalisme merupakan salah satu tujuan utama sebagaimana tertuang dalam Pendidikan Pancasila dan Kewarganegaraan, dimana pada setiap jenjang pendidikan dan bahkan didunia perkuliahan pembelajaran Pancasila dan Kewarganegaraan juga ada. Oleh karena itu, maka nilai nasionalisme dalam lingkungan sekolah atau madrasah sangat penting ditanamkan bagi peserta didik seperti pembiasaan untuk menjaga nama baik sekolah, menyanyikan lagu nasional, penggunaan bahasa Indonesia yang baik dan benar, penghormatan bendera merah putih. ${ }^{6}$

Berdasarkan pemaparan di atas, peneliti melakukan penelitian di Madrasah Ibtida'iyah Maarif Condro Jember, dengan asumsi bahwa lembaga ini merupakan salah satu lembaga pendidikan swasta yang sudah berdiri sejak tahun 1957, yang sudah lama berdiri, diterima dan diakui oleh

\footnotetext{
${ }^{5}$ Novan Ardy Wiyani, Konsep, Praktik dan Strategi Membumikan Pendidikan Karakter di SD, (Yogyakarta: Ar Ruzz Media, 2013), 169.

${ }^{6}$ Masnur Muslih, Pendidikan Karakter, (Jakarta: PT Raja Grafindo, 2014), 154.
} 
masyarakat. Dibuktikan dengan banyaknya peserta didik yang sekolah di lembaga tersebut yakni berjumlah 326 anak. Hal ini menunjukkan bahwa banyak orangtua/ masyarakat mempercayakan lembaga tersebut sebagai tempat menuntut ilmu bagi anaknya.

Sebagaimana hasil wawancara dengan salah satu orang tua peserta didik mengatakan bahwa:

Karena menurut saya di sekolah ini jika dibandingkan dengan sekolah lainnya yang ada sekitar sini, yang memiliki prestasi cukup bagus ya di sekolah ini. Banyak siswa yang meraih prestasi ketika lomba-lomba itu. Saat olimpiade juga mendapatkan juara. Jadi saya juga kepingin anak saya seperti itu jadi saya sekolahkan di sini. ${ }^{7}$

Sebagai lembaga pendidikan yang bertanggung jawab untuk melahirkan dan menjadikan peserta didiknya sebagai generasi penerus bangsa yang kompetitif, menumbuhkan rasa cinta tanah air bagi anak didiknya yang merupakan hal penting untuk dilakukan oleh madrasah. Penelitian ini difokuskan pada bagaimana proses dan makna internalisasi nilai karakter nasionalis pada pembelajaran PPKN di Madrasah Ibtida'iyah Maarif Condro Jember.

Dalam Undang-Undang No.24 tahun 2009 tentang Bendera, Bahasa dan Lambang serta lagu kebangsaan, sebagaimana tertuang pada pasal 62 menyebutkan bahwa "setiap orang yang hadir pada saat lagu kebangsaan diperdengarkan dan atau dinyanyikan, wajib berdiri tegak dengan sikap hormat”. Inti dari pasal ini, diharapkan akan membentuk sikap nasionalisme pada siapa saja yang menyanyikanya atau mendengarkan lagu kebangsaan Indonesia Raya. Sekolah atau madrasah merupakan tempat yang bisa digunakan untuk menumbuhkan rasa cinta tanah air bagi anak didik. Salah satunya dengan menyanyikan lagu kebangsaan Indonesia Raya secara langsung. Siswa diharapkan dapat menjiwai nilai-nilai yang terkandung dalam lagu tersebut sehingga memunculkan semangat dan jiwa kebangsaan.

\footnotetext{
${ }^{7}$ Saputri, Wawancara, Jember, 07 Februari 2020
} 
Hal ini juga sesuai dengan nilai-nilai nasionalisme yang dijelaskan oleh Praesty Hardyana Dewi dan Warsono bahwa:

Dalam upaya penanaman nasionalisme peserta didik setiap sekolah di haruskan untuk memperingati hari pahlawan, Setiap warga negara Indonesia harus patuh terhadap aturan yang berlaku di negara Indonesia, Setiap warga negara harus hafal Pancasila, UUD 1945 mampu menjadi pedoman dalam membangun kesejahteraan rakyat Indonesia".

Dalam pembelajaran, khususnya pada pembelajaran Pendidikan Pancasila dan Kewarganegaraan, tujuan dari pendidikan pancasila dan kewaragenagaraan adalah untuk membentuk warga negara menjadi warga negara yang baik (good citizenship) yaitu diantaranya dengan membetuk warga negara menjadi warga negara yang memiliki pengetahuan (civic knowledge), kecakapan dan kemampuan sikap kewarganegaraan (civic dispositions), kecakapan dan kemampuan keterampilan kewarganegaraan (civic skill). Hal ini selaras dengan nilai-nilai nasionalisme di sekolah, dimana dalam nilai-nilai nasionalisme di sekolah juga dapat membentuk peserta didik yang baik atau menjadi warga negara yang baik yaitu dengan lebih mendahulukan kepentingan umum dari pada kepentingan pribadi, mengikuti upacara bendera, menaati peraturan sekolah, belajar dengan sungguh-sungguh. ${ }^{8}$

Berdasarkan uraian di atas, perlu adanya pemikiran untuk mengkaji nilai-nilai nasionalisme agar diterapkan dan diamalkan di dunia pendidikan, karena peserta didik merupakan harapan bangsa yang akan membawa bangsanya kearah pembangunan di Indonesia. Nilai-nilai yang terkandung dalam nasionalisme memiliki arti yang sangat penting bagi kehidupan bangsa dan khususnya pendidikan di Indonesia. Nilai-nilai nasionalisme ini menjadi landasan dan bagian dari kurikulum, serta acuan-acuan dalam pelaksanaan tata nilai yang berlaku di sekolah dan mempengaruhi langsung terhadap mutu, kualitas pribadi dan sikap nasionalisme dalam diri peserta didik. Nilai nasionalisme yang diterapkan di sekolah yaitu membangun karakter (Nation)

\footnotetext{
${ }^{8}$ Azyumardi Azra, Pendidikan Kewarganegaraan, (Jakarta: Praneda Media, 2003), 92.
} 
yang berarti bersifat memperbaiki, membina, mendirikan, mengadakan sesuatu. Sedangkan "Karakter" adalah tabiat, watak, sifat-sifat kejiwaan, akhlak atau budi pekerti yang membedakan seseorang dari yang lain.

Dalam konteks ini, suatu proses atau usaha yang dilakukan untuk membina, memperbaiki dan atau membentuk tabiat, watak, sifat kejiwaan, akhlak mulia, iman manusia sehingga menunjukkan perangai dan tingkah laku yang baik berlandaskan nilai-nilai Pancasila. Dari latar belakang yang telah dikemukakan, maka peneliti melakukan penelitian dengan judul "Internalisasi Nilai-nilai Nasionalisme dalam Pembelajaran PPKN di Madrasah Ibtidaiyah Maarif Condro Jember".

\section{METODE PENELITIAN}

Peneliti dalam penelitian menggunakan pendekatan kualitatif, dengan jenis penelitian deskriptif. Subyek penelitian yang dijadikan informan menggunakan purposive sampling. Purposive sampling adalah teknik pengambilan sampel sumber data dengan pertimbangan tertentu. ${ }^{9}$ Pertimbangan tertentu ini adalah orang yang akan dijadikan informan yaitu orang yang dapat memberikan informasi berupa data yang diperlukan oleh peneliti. Berdasarkan uraian tersebut, yang dijadikan sebagai subyek penelitian ini adalah: (1) Kepala Madrasah (2) Guru kelas IVB , dan (3) Peserta didik.

Adapun teknik yang digunakan untuk mengumpulkan data dalam penelitian ini adalah teknik observasi, teknik wawancara dan teknik dokumentasi. Sedangkan analisis data dalam penelitian ini, menggunakan analisis Miles, Huberman, dan Saldana, yakni analisis data dalam penelitian kualitatif dengan tiga alur aktivitas/ kegiatan secara bersamaan. Aktivitas yang terjadi meliputi: kondensasi data, penyajian data, dan penarikan

9 Sugiyono, Metode Penelitian Kuantitatif Kualitatif dan $R \& D$, (Bandung: Alfabeta, 2016), 216 
kesimpulan/ verifikasi. ${ }^{10}$ Kondensasi data adalah proses pemilihan, pemfokusan, penyederhanaan, mengabstraksi, dan/atau mentransformasikan data dari catatan lapangan yang ditulis, transkrip wawancara, dokumen, dan bahan empiris lainnya. Penyajian data adalah sebuah pengorganisasian, penyatuan dan informasi yang memungkinkan penyimpulan dan tindakan. Kegiatan analisis yang ketiga adalah menarik kesimpulan dan verifikasi. Dari permulaan pengumpulan data, seorang penganalisis kualitatif mulai mencari arti benda-benda, mencatat keteraturan penjelasan, konfigurasikonfigurasi yang mungkin, alur sebab akibat, proporsi, kesimpulankesimpulan "final" mungkin tidak muncul sampai pengumpulan data berakhir, tergantung besarnya kumpulan-kumpulan catatan lapangan, pengkodeannya, penyimpanan, dan metode pencarian ulang yang digunakan, kecakapan peneliti, dan tuntutan-tuntutan pemberian data.

\section{HASIL DAN PEMBAHASAN TEMUAN}

Berdasarkan data-data dan informasi yang diperoleh melalui wawancara, observasi dan studi dokomentasi dilapangan, maka dapat dilakukan pembahasan sebagai berikut :

\section{Strategi Internalisasi Nilai Nasionalis Pada Pembelajaran PPKN di Madrasah Ibtidaiyah Maarif Condro Jember}

Nasionalisme merupakan suatu paham yang menganggap kesetiaan tertinggi atas setiap pribadi harus disertakan pada negara kebangsaan (Nation State) atau sebagai sikap mental atau tingkah laku individu ataupun masyarakat yang menunjukan adanya loyalitas atau dan pengabdian yang tinggi terhadap bangsa dan negaranya. Nasionalisme sangat diperlukan

\footnotetext{
${ }^{10}$ Miles, B. Mathew, A. Michael Huberman, dan Johny Saldana, Qualitative Data Analysis A Methods Sourcebook,(America: Arizona State Unversity, 2014), 14.
} 
dalam kelangsungan suatu negara, dengan harapan memunculkan rasa persatuan didalam negara tersebut. ${ }^{11}$

Konsep internalisasi nilai-nilai nasionalisme yang dilakukan di Madrasah Ibtidaiyah Maarif Condro dalam pembelajaran PPKN ini adalah mamasukkan nilai-nilai nasionalisme dalam pembelajaran PPKN melalui metode pembelajaran yang mampu diterima oleh peserta didik agar peserta didik bisa menjadi warga negara yang baik dan bisa memberikan kontribusi dalam memajukan bangsanya dimasa depan.

Sebagaimana hasil wawancara dengan kepala sekolah yang mengatakan bahwa:

Internalisasi nilai-nilai nasionalisme dilakukan dengan beberapa strategi, misalnya strategi pemberian nasihat yang dilakukan guru kelas pada saat sela-sela pelajaran di kelas. Juga nasihat ketika upacara pada hari senin mengenai berbagai hal yang meningkatkan pemahaman dan kesadaran siswa dalam kehidupan sekolah, keluarga dan masyarakat. Misalnya saja nasihat terkait kewajiban manusia terhadap Allah, sikap anak terhadap guru dan orang tua juga perilaku siswa terhadap teman sebaya. Agar selalu tertanam pada diri siswa nilai-nilai nasionalisme, dalam hal pembelajaran internalisasi nilai-nilai nasionalisme juga dilakukan guru melalui pembelajaran PPKN yakni menggunakan berbagai pendekatan dan strategi pembelajaran yang dirasa mampu untuk menanamkan nilai-nilai nasionalisme pada siswa. ${ }^{12}$

Pernyataan tersebut didukung dengan hasil wawancara dengan guru kelas IV yang mengatakan bahwa:

Strategi dalam internalisasi nilai-nilai nasionalisme dapat menggunakan berbagai macam strategi diantaranya selalu memberikan nasihat diselasela pembelajaran serta dapat menggunakan berbagai macam media pembelajaran, agar pembelajaran dikelas tidak monoton sehingga peserta didik akan senang dan tertarik dengan materi yang disampaikan. Seperti memberi contoh-contoh tentang nilai-nilai nasionalisme, agar peserta didik lebih mencintai tanah air dan lebih mengenal budaya bangsa, serta biasa dengan kehidupan yang bersifat positif. Sehingga peserta didik semangat belajar, berusaha menerapkan sikap

\footnotetext{
${ }^{11}$ Rahmat Mulyana, Mengartikulasikan Pendidikan Nilai, (Bandung: CV Alfabeta, 200), 132

${ }^{12}$ Poniman, Wawancara, Jember, 06 Februari 2020
} 
nasionalisme dalam kehidupan sehari-hari baik dalam lingkungan keluarga, sekolah, maupun masyarakat. ${ }^{13}$

Konsep internalisasi nilai-nilai nasionalisme yang dilakukan di Madrasah Ibtidaiyah Maarif Condro, terlihat pada penggunaan berbagai strategi yang akan digunakan dalam pembelajaran PPKN. Sebagaimana tertuang dalam RPP, yang dijadikan sebagai tahap awal perencanaan pembelajaran PPKN. Strategi yang dimasukkan salah satunya adalah Strategi Cooperative Learning Tipe Jigsaw, dimana Guru membagi setiap kelas menjadi beberapa kelompok, dengan setiap kelompok terdiri dari 4-6 siswa dengan kemampuan yang berbeda. Kelompok tersebut disebut kelompok asal. Jumlah anggota dalam kelompok asal menyesuiakan dengan jumlah bagian materi pelajaran.

Sebagaimana hasil wawancara dengan guru kelas IV, mengatakan bahwa:

Agar nilai-nilai nasionalisme dalam pembelajaran PPKN dapat diinternalisasikan pada peserta didik, maka perlu adanya sebuah strategi yang menunjang pada pembelajaran PPKN ini. Salah satunya adalah Strategi Cooperative Learning Tipe Jigsaw, dalam hal ini saya menyesuaikan dengan materi PPKN yang ada pada buku siswa dengan langkah-langkah yang akan dilakuakan dalam Strategi Cooperative Learning Tipe Jigsaw ini. Dimana nantinya strategi ini akan difokuskan pada target kompetensi yang akan dicapai pada muatan PPKN, yakni materi terkait civic knowledge, civic skills dan civic disposition dengan banyak memberi contoh-contoh tentang manifestasi nilai nilai nasionalisme, agar peserta didik lebih mencintai tanah air dan lebih mengenal budaya bangsa, serta biasa dengan kehidupan yang bersifat positif. ${ }^{14}$

Konsep internalisasi nilai-nilai nasionalisme yang dilakukan di Madrasah Ibtidaiyah Maarif Condro, dilakukan secara sistematis dengan tujuan nilai-nilai nasionalisme dapat diinternalisasikan pada peserta didik melalui pembelajaran PPKN. Mulai dari tahap perencanaan guru dalam

\footnotetext{
${ }^{13}$ Rismala, Wawancara, Jember, 06 Februari 2020

${ }^{14}$ Rismala, Wawancara, Jember, 06 Februari 2020
} 
menyiapkan RPP, dengan menggunakan strategi yang diperlukan dalam menunjang proses internalisasi pada tahap langkah-langkah pembelajaran serta strategi yang digunakan. Pelaksanaan pembelajaran disesuaikan dengan perancanaan-perencanaan yang telah dibuat oleh guru kelas dan menyesuaikan dengan evaluasi yang akan dilakukan.

\section{Penerapan Nilai Nasionalisme dalam Pembelajaran PPKN Di Madrasah Ibtidaiyah Maarif Condro Jember}

Dalam penelitian ini, internalisasi nilai-nilai karakter yang ditanamkan melalui kegiatan pembelajaran PPKN, karena PPKN merupakan mata pelajaran wajib di sekolah yang saat ini sudah terintegrasi dalam bentuk tema, akan tetapi muatan dalam kompetensi dasar PPKN tetap sama. PPKN dibebani tanggung jawab yang berat sebagai wahana untuk mendidik siswa menjadi warga negara yang cerdas, kritis dan taat kepada hukum yang berlaku dan berakhlak mulia.

Nilai karakter nasionalis diintegrasikan dalam proses pembelajaran PPKN dilakukan dengan cara mengenalkan, memfasilitasi, dan menginternalisasikan nilai karakter nasionalis didalam perilaku sehari-hari. Nilai karakter tersebut diinternalisasikan pada peserta didik melalui proses pembelajaran PPKN, karena dianggap penting, seiring gejala memudarnya jati diri ke-Indonesia-an di kalangan pelajar saat ini.

Banyak siswa yang mengungkapkan bahwa, mereka pernah bersikap tidak nasionalis, misalnya tidak mendengarkan guru yang menjelaskan di depan kelas. Seperti yang kita tahu bahwa nasionalisme memiliki kaitan erat dengan budaya bangsa dan pandangan hidup pancasila. Sikap nasionalisme merupakan salah satu tanda kebanggaan seseorang terhadap bangsanya.

Internalisasi nilai karakter nasionalis diartikan sebagai proses penanaman nilai nasionalis ke dalam jiwa seseorang sehingga nilai tersebut 
tercermin pada sikap dan perilaku yang ditampakkan dalam kehidupan sehari-hari (menyatu dengan pribadi). ${ }^{15}$

Dalam hal ini, penanaman nilai-nilai nasionalisme dilakukan dengan berbagai macam strategi pendekatan pembelajaran khususnya dalam pembelajaran PPKN, agar pembelajaran dikelas tidak monoton sehingga peserta didik akan senang dan tertarik dengan materi yang disampaikan. Penggunaan strategi Cooperative Learning Tipe Jigsaw merupakan salah satu strategi yang dirasa dapat memebantu proses penanaman nilai-nilai nasionalisme dalam diri peserta didik melalui pembelajaran PPKN ini.

Terlihat dalam pelaksanaan pembelajaran guru membagi setiap kelas menjadi beberapa kelompok, dengan setiap kelompok terdiri dari 4-6 siswa dengan kemampuan yang berbeda. Kelompok tersebut disebut kelompok asal. Jumlah anggota dalam kelompok asal menyesuian dengan jumlah bagian materi pelajaran. Yang akan di pelajari siswa dengan tujuan pembelajaran akan dicapai. Dalam tipe jigsaw ini, setiap siswa diberi tugas mempelajari materi civic knowledge, civic skills dan civic disposition pada pembelajaran PPKN tersebut. Semua siswa dengan materi pembelajaran yang sama belajar bersama dalam kelompok yang disebut ahli siswa mendiskusikan bagian materi pembelajaran yang sama, serta menyusun rencana bagaimana menyampaikan kepada temannya jika kembali kekelompok asal.

Sebagaimana hasil wawancara dengan Beryl siswa kelas IV yang mengatakan bahwa:

Saat pelajaran PPKN, kami selalu senang karena pelajarannya tidak membosankan, selalu menarik, bu Risma juga sangat baik, kami biasanya dibagi kedalam beberapa kelompok. Bu Risma juga sering memberikan contoh contoh nilai nasionalisme dan meminta kami untuk menjelaskan kembali sesuai kelompok. Saya suka dengan materi adat istiadat, tari-tarian, lagu-lagu nasional dan daerah, bu Risma juga selalu mengajarkan toleransi dengan menghormati keragaman budaya,

15 Rahmat Mulyana, Mengartikulasikan Pendidikan Nilai. (Bandung: CV Alfabeta, 200), 112. 
suku,dan agama lain. Saya suka pelajarannya karna pelajaran selalu menarik dan menyenangkan. ${ }^{16}$

Proses internalisasi dapat dialami langsung oleh siswa ketika mereka mendengar secara langsung dari guru mereka dalam menginformasikan kebaikan dari nilai karakter nasionalis dan kekurangannya apabila tidak memiliki nilai katakter tersebut ${ }^{17}$. Berdasarkan hasil wawancara yang dilakukan kepada informan menunjukkan secara berbeda-beda mereka memaknai nilai karakter nasionalis yang disampaikan oleh guru mereka. Adapun sub nilai karakter nasionalis yang disampaikan oleh guru mereka yaitu disiplin, cinta tanah air, semangat kebangsaan, cinta damai, peduli lingkungan, menghargai prestasi, dan toleransi dengan menghormati keragaman budaya, suku,dan agama lain.

\section{SIMPULAN}

Berdasarkan analisis data dan pembahasan penelitian tentang Internalisasi Nilai Nasionalisme Dalam Pembelajaran PPKN Di Madrasah Ibtidaiyah Maarif Condro Jember hasil penelitian sebagai berikut: (a) Strategi Internalisasi nilai-nilai nasionalisme yang dilakukan di Madrasah Ibtidaiyah Maarif Condro dalam pembelajaran PPKN ini adalah mamasukkan nilai-nilai nasionalisme dalam pembelajaran PPKN melalui metode pembelajaran yang mampu diterima oleh peserta didik agar peserta didik bisa menjadi warganegara yang baik dan bisa memberikan kontribusi dalam memajukan bangsanya dimasa depan. (b) Pelaksanaan internalisasi nilai nasionalisme diperoleh siswa ketika mereka mendengar secara langsung guru mereka menginformasikan kebaikan dari nilai karakter nasionalis dan kekurangannya apabila tidak memiliki nilai katakter tersebut, dalam hal ini guru memanfaatkan berbagai strategi agar internalisasi nilai

\footnotetext{
${ }^{16}$ Rismala, Wawancara, Jember, 06 Februari 2020.

${ }^{17}$ Pupuh Fathurrohman, Pengembangan Pendidikan Karakter, (Bandung: Refika Aditama, 2013), 15.
} 
nasionalisme dapat tertanam pada siswa, yakni menggunakan Strategi Cooperative Learning Tipe Jigsaw.

\section{DAFTAR PUSTAKA}

Adisusilo, Sutarjo. Pembelajaran Nilai Karakter: Konstruktiisme dan CT sebagai Inovasi Pendekatan Pembelajaran Afektif. Jakarta: Rajawali Pers, 2013.

Fathurrohman, Pupuh. Pengembangan Pendidikan Karakter. Bandung: Refika Aditama, 2013.

Gunawan, Heri. Pendidikan Karakter Konsep dan Implementasi. Bandung: Alfabeta, 2012.

Harahap, Asriana. "Implementasi Nilai Nilai Karakter Pada Pembeljaran $P P K N$ ', Jurnal Pendidikan Madrasah Ibtidaiyah (Online), Vol.1 No.1, 2018.

Koesoema, Doni. Pendidikan Karakter Strategi Pendidik Anak di Zaman Global. Jakarta: Grasindo, 2007.

Mathew, Miles, B.A. Michael Huberman, dan Johny Saldana. Qualitative Data Analysis A Methods Sourcebook. America: Arizona State Unversity, 2014.

Mulyana, Rahmat. Mengartikulasikan Pendidikan Nilai. Bandung: CV Alfabeta, 2014.

Mulyasa, E. Pengembangan dan Implementasi Kurikulum 2013, Bandung: Remaja Rosdakarya, 2013.

Rodliyah. Pendidikan \& Ilmu Pendidikan. Jember: STAIN Jember Press, 2013.

Rukmana, Nana. Strategi Partnering. Semarang: Alfabeta, 2006.

Sanjaya, Wina. Strategi Pembelajaran Berorientasi Standart Proses Pendidikan. Jakarta: Prenadamedia Group, 2016.

Sugiyono. Metode Penelitian Kuantitatif Kualitatif dan $R \& D$. Bandung: Alfabeta, 2016.

Susanto, Ahmad. Teori Belajar \& Pembelajaran di Sekolah Dasar. Jakarta: Prenadamedia Group, 2006.

US, Supardi. "Arah Pendidikan di Indonesia dalam Tataran Kebijakan dan Implementasi”. Jurnal Formatif (Online), Vol. 2 No.2. 2012.

Utomo, Eko Prasetro. "Internalisasi Karakter Nasionalisme". Jurnal Formatif Online. Vol. 2 No. 2, 2012. 